\title{
Translation, cross-cultural adaptation and applicability of the Brazilian version of the Frontotemporal Dementia Rating Scale (FTD-FRS)
}

\author{
Thais Bento Lima-Silva', Valéria Santoro Bahia', Viviane Amaral Carvalho², \\ Henrique Cerqueira Guimarães², Paulo Caramelli², Márcio Balthazar ${ }^{3}$, \\ Benito Damasceno ${ }^{3}$, Cássio Machado de Campos Bottino ${ }^{4}$, Sônia Maria Dozzi Brucki', \\ Eneida Mioshi5 ${ }^{5}$ Ricardo Nitrini', Mônica Sanches Yassuda ${ }^{1}$
}

\begin{abstract}
Background: Staging scales for dementia have been devised for grading Alzheimer's disease (AD) but do not include the specific symptoms of frontotemporal lobar degeneration (FTLD). Objective: To translate and adapt the Frontotemporal Dementia Rating Scale (FTD-FRS) to Brazilian Portuguese. Methods: The cross-cultural adaptation process consisted of the following steps: translation, back-translation (prepared by independent translators), discussion with specialists, and development of a final version after minor adjustments. A pilot application was carried out with 12 patients diagnosed with bvFTD and 11 with $A D$, matched for disease severity (CDR=1.0). The evaluation protocol included: Addenbrooke's Cognitive Examination-Revised (ACE-R), Mini-Mental State Examination (MMSE), Executive Interview (EXIT25), Neuropsychiatric Inventory (NPI), Frontotemporal Dementia Rating Scale (FTD-FRS) and Clinical Dementia Rating scale (CDR). Results: The Brazilian version of the FTD-FRS seemed appropriate for use in this country. Preliminary results revealed greater levels of disability in bvFTD than in AD patients (bvFTD: 25\% mild, 50\% moderate and 25\% severe; AD: $36.36 \%$ mild, $63.64 \%$ moderate). It appears that the CDR underrates disease severity in bvFTD since a relevant proportion of patients rated as having mild dementia $(C D R=1.0)$ in fact had moderate or severe levels of disability according to the FTD-FRS Conclusion: The Brazilian version of the FTD-FRS seems suitable to aid staging and determining disease progression. Key words: frontotemporal lobar degeneration, behavioral variant frontotemporal dementia, Alzheimer dementia, clinical staging, disease progression.
\end{abstract}

\section{TRADUÇÃ0, ADAPTAÇÃO TRANSCULTURAL E APLICABILIDADE DA ESCALA DE ESTADIAMENTO E PROGRESSÃO DA DEGENERAÇÃO LOBAR FRONTOTEMPORAL}

RESUMO. Introdução: As escalas de estadiamento das demências, como a Clinical Dementia Rating (CDR), foram elaboradas para graduar a doença de Alzheimer (DA) e não incluem os sintomas específicos da degeneração lobar frontotemporal (DLFT). Objetivo: Realizar a tradução e adaptação cultural da Frontotemporal Dementia Rating Scale (FTD-FRS) para o contexto brasileiro e apresentar dados preliminares da sua aplicabilidade. Métodos: 0 processo de adaptação transcultural consistiu em: tradução, retrotradução (realizadas por tradutores independentes), discussão com especialistas sobre a versão em português e equivalência com a versão original, desenvolvimento da versão final com pequenos ajustes. Foi feita uma aplicação piloto em 12 pacientes com diagnóstico de demência frontotemporal variante comportamental (DFTvc) e 11 com DA, pareados quanto à gravidade da demência $(C D R=1)$. 0 protocolo de avaliação incluiu a Addenbrooke's Cognitive Examination-Revised (ACE-R), Mini Exame do Estado Mental (MEEM), Executive Interview (EXIT-25), Inventário Neuropsiquiátrico (INP) e a Escala de Avaliação Clínica da Demência (CDR). Resultados: A FTD-FRS na versão brasileira pareceu apropriada. Resultados preliminares revelaram maiores níveis de incapacidade na DFTvc do que em pacientes com DA (DFTvc: 25\% leve, 50\% moderado, 25\% grave; AD: 36.36\% leve, 63.64\% moderado). A CDR parece subestimar a gravidade da demência na DFTvc, uma vez que uma relevante proporção dos pacientes classificados com leves (CDR=1) de fato apresentaram nível moderado ou grave de comprometimento na FTD-FRS. Conclusão: A versão brasileira da FTD-FRS pode se mostrar adequada para auxiliar no estadiamento e determinar a progressão da DLFT.

Palavras-chave: degeneração lobar frontotemporal, demência frontotemporal variante comportamental, doença de Alzheimer, estadiamento clínico, progressão da doença.

${ }^{1}$ Neurology Department, University of São Paulo, São Paulo SP, Brazil. ${ }^{2}$ Behavioral and Cognitive Neurology Unit, Department of Internal Medicine, Federal University of Minas Gerais, Belo Horizonte MG, Brazil. ${ }^{3}$ Neuropsychology and Dementia Unit, Department of Neurology, University of Campinas, São Paulo SP, Brazil. ${ }^{4}$ Old Age Research Group (PROTER), Institute of Psychiatry, University of São Paulo, São Paulo SP, Brazil. ${ }^{5}$ Neuroscience Research Austrália, Sydney, NSW, Australia.

Mônica Sanches Yassuda. Av. Dr. Eneás de Carvalho Aguiar, 255 - 05403-100 São Paulo SP - Brazil. E-mail: yassuda@usp.br

Disclosure: The authors report no conflicts of interest.

Received August 20, 2013. Accepted in final form November 11, 2013. 


\section{INTRODUCTION}

The term Frontotemporal Lobar Degeneration 1 (FTLD) was first introduced in 1998 by a group of Swedish and English researchers, ${ }^{1}$ who used it to describe a clinical syndrome characterized by progressive behavioral changes associated with atrophy of the frontal lobes and of the anterior portions of the temporal lobes. The term was introduced in order to replace terminology such as "frontal lobe degeneration of nonAlzheimer type" and "dementia of frontal lobe type". ${ }^{1}$ Three main conditions are described in the FTLD group: frontotemporal dementia (FTD) or behavioral variant frontotemporal dementia (bvFTD), ${ }^{2,3}$ semantic dementia (SD), ${ }^{4}$ and progressive non-fluent aphasia (PNFA). ${ }^{4-6}$

Recent studies have suggested that FTLD-related diseases have a significant impact on the ability to carry out daily activities. However, studies on disability severity in these conditions are scarce. In addition, disease staging in FTLD remains a challenge as most dementia staging tools have been developed for Alzheimer's disease (AD). For instance, the Clinical Dementia Rating, ${ }^{7}$ and other similar instruments may not capture the functional changes that are specific to FTLD. A recently developed scale specifically designed to examine the behavioral and functional changes associated with FTLD, the Frontotemporal Dementia Rating Scale (FTD-FRS), has been found to be helpful for assessing severity and the rate of functional decline. ${ }^{8}$

In the validation study of the FTD-FRS, ${ }^{8}$ by crosssectional analyses involving a sample with three FTLD variants (bvFTD, $n=29 ; S D, n=20$; PNFA, $n=28$ ), the authors were able to identify six levels of disease severity (very mild, mild, moderate, severe, very severe and advanced/profound) with the use of the FTD-FRS. There was greater severity of functional impairment in bvFTD than in language variants, and limited correlation with cognitive measures. Follow-up analyses of a sub-sample carried out using the FRS after 12 months revealed that patients with bvFTD advanced more rapidly through the severity stages than the other variants. Therefore, the FTD-FRS was able to distinguish the functional profile of FTLD variants and identify differential rates of decline.

In Brazil, no studies investigating FTLD staging have yet been conducted and validated tools for this purpose are lacking. Therefore, the primary aim of the present study was to translate the FTD-FRS to Brazilian Portuguese and adapt it to the Brazilian cultural context.

\section{METHODS}

The translation and cross-cultural adaptation processes consisted of the following steps: translation, back-translation (prepared by independent translators), evaluation of the back-translated version against the original version, discussion of the Portuguese version of the FTD-FRS with specialists, development of a final version after minor adjustments, and pilot application in patients with diagnoses of bvFTD and AD. The original instrument, translation, back-translation and the final version of the FTD-FRS are given in Table 1 and Appendix A. Table 2 shows percentage scores and logarithmic score conversion for the FTD-FRS correction.

Participants. For this stage of the study it was decided to include in the research sample only patients with bvFTD. Additionally, this variant of FTLD presents features discussed in the scale (disorders of behavior and impact on activities of daily living) that could help in the detection of its applicability in Brazil.

The study sample consisted of 23 individuals aged 45 or older, with at least two years of formal education - 12 had been diagnosed with bvFTD and 11 with AD. Patients were matched for disease severity $(C D R=1.0)$. This study was conducted from February 2011 to July in 2013.

Dementia was diagnosed according to the Diagnostic and Statistical Manual of Mental Disorders - DSMIV criteria. ${ }^{9}$ For the bvFTD diagnosis, the international consensus criteria were used. ${ }^{2} \mathrm{AD}$ diagnosis followed the National Institute of Neurological and Communicative Disorders and Stroke and the Alzheimer's Disease and Related Disorders Association - NINCDS-ADRDA criteria for probable AD dementia. ${ }^{10}$

The exclusion criteria were as follows: $C D R>1$, visual, hearing or motor impairments which could hinder comprehension of instructions and execution of cognitive tasks, uncontrolled clinical conditions, severe psychiatric disorders, and significant cerebrovascular disease on neuroimaging.

Evaluation procedures. The evaluation protocol included: sociodemographic and clinical questionnaires; Addenbrooke's Cognitive Examination-Revised (ACE-R) MiniMental State Examination (MMSE); Executive Interview (EXIT-25).The protocol for caregivers included the Cornell Scale for Depression in Dementia, Disability Assessment for Dementia (DAD), Neuropsychiatric Inventory (NPI), the Frontotemporal Dementia Rating Scale (FRS) and Clinical Dementia Rating scale (CDR).

The ACE-R and the EXIT-25 were applied to assess cognitive performance. The ACE-R consists of a brief cognitive assessment battery testing five different cog- 


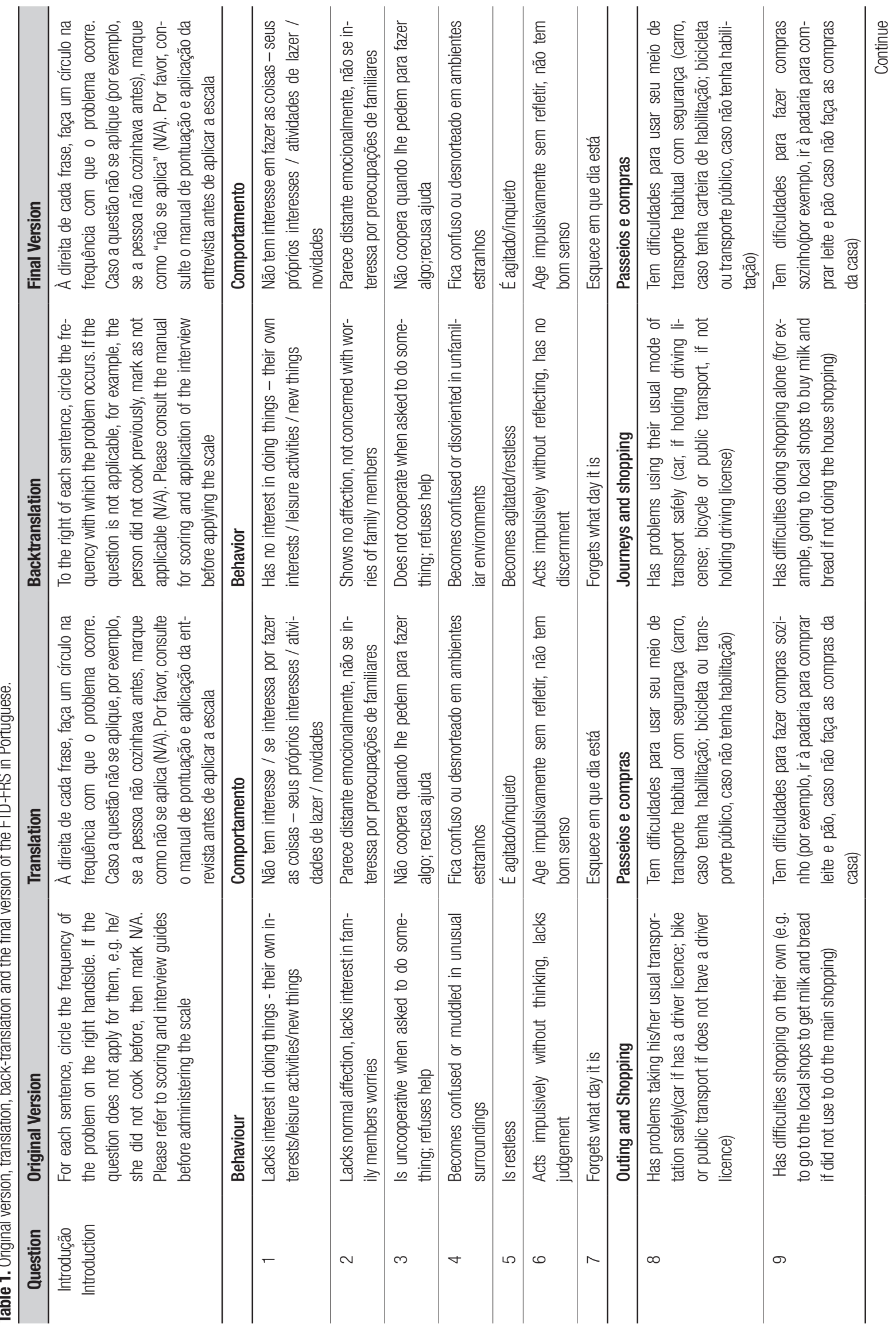




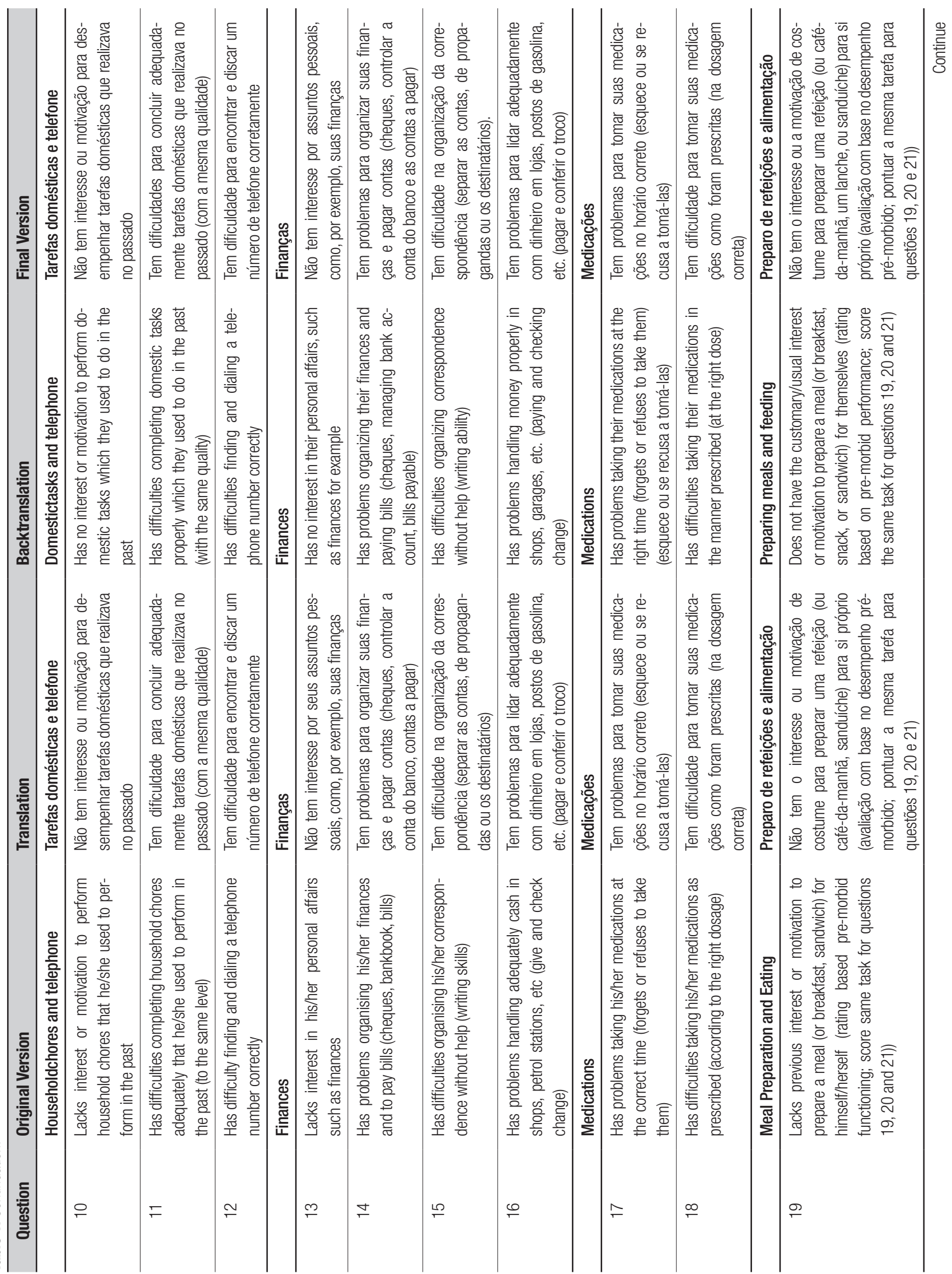




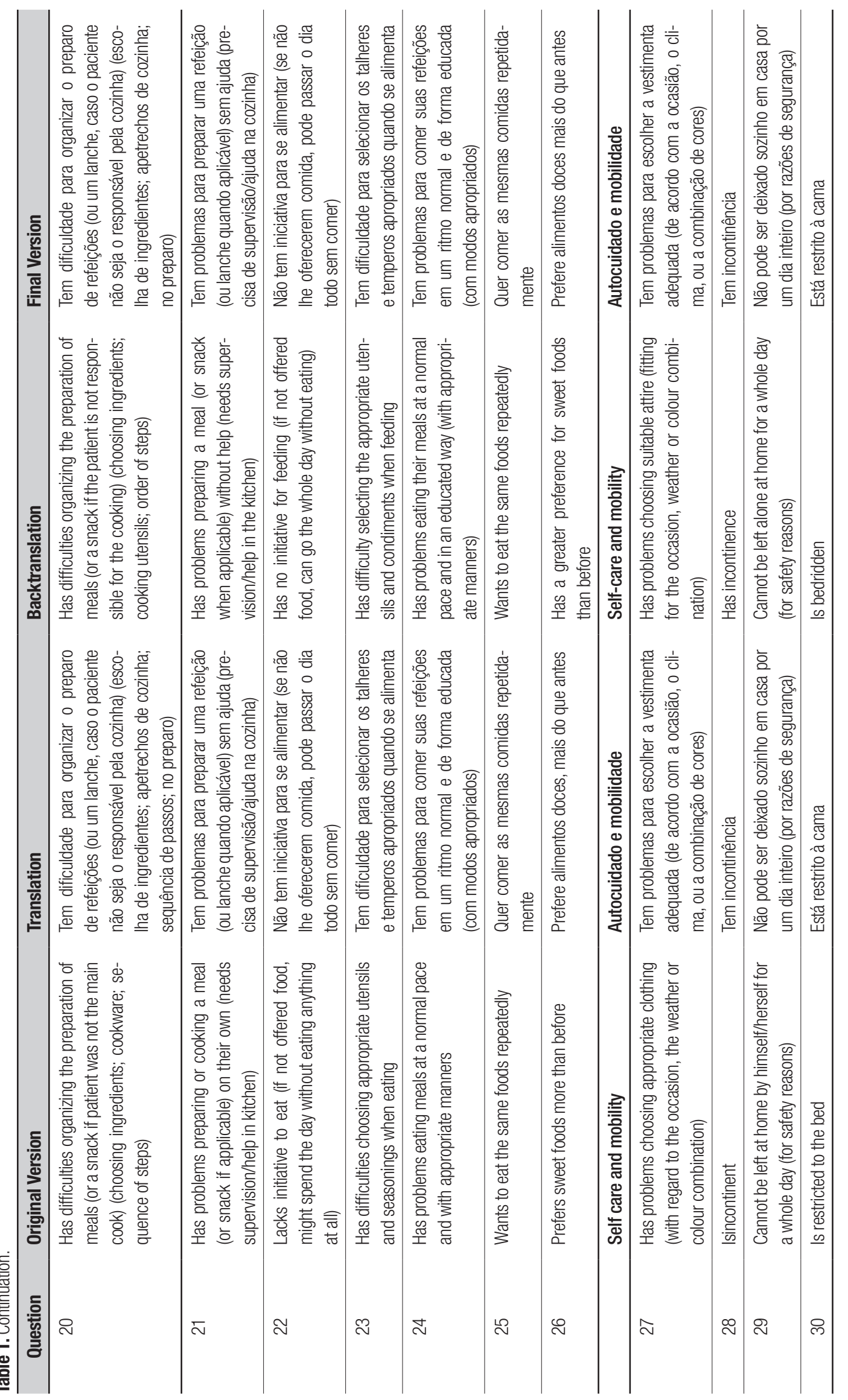


Table 2. Percentage score and logarithmic score conversion of FTP-FRS.

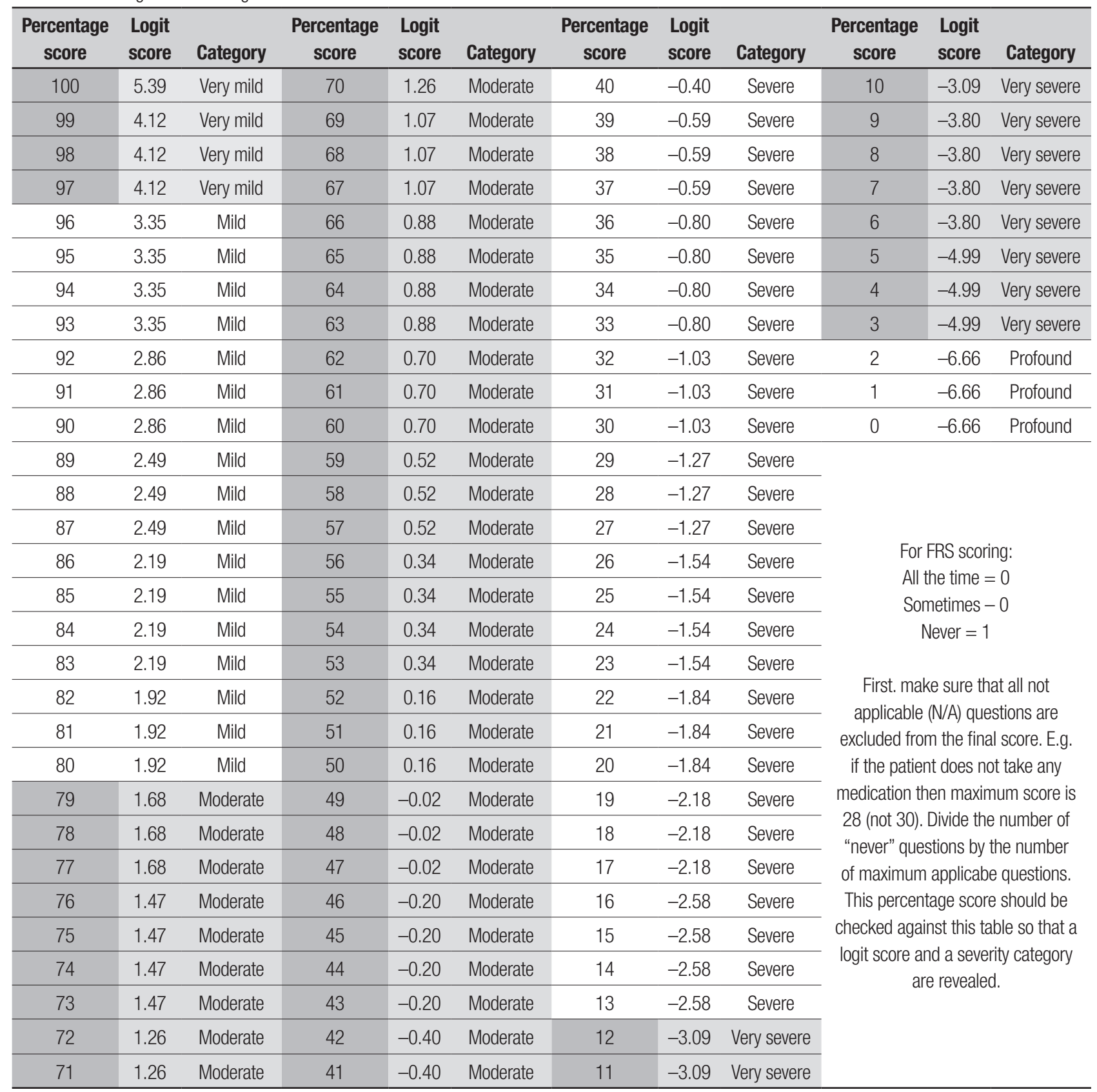

nitive domains. The highest score is 100 points, distributed as follows: attention and orientation (18); memory (35); verbal fluency (14); language (28); and visuo-spatial abilities (5). Higher scores indicate better performance. The scores regarding each of the six domains can be computed separately and their sum generates the total ACE-R score of which 30 points corresponds to the MMSE. ${ }^{11,12}$

The EXIT-25 assesses different aspects of executive function. It consists of 25 sub-items with scores ranging from 0 to 2, with total score ranging from 0 to 50 , and lower scores indicating better performance. It assesses verbal fluency, design fluency, anomalous sentence repetition, and interference, among others. Studies have suggested that a score higher than 15 is consistent with dementia. ${ }^{13,14}$

For dementia staging, the CDR was completed. It evaluates six domains related to cognitive and functional performance: memory, orientation, judgment and problem solving, community affairs, home and hobbies, 
and personal care. ${ }^{7,15} \mathrm{~A}$ pre-defined algorithm allows the calculation of a total score, with 0 indicating preserved performance and higher scores indicating increased impairment. ${ }^{7}$

The Neuropsychiatric Inventory (NPI) in its short version is a 10-item questionnaire that makes it possible to determine the presence of neuropsychiatric and behavioral symptoms, their frequency and severity. Scores range from 0 to 144 . Each behavior has a maximum score of 12 points, calculated by multiplying symptom frequency by its severity. The assessed behaviors are: delusions, hallucinations, agitation and aggression, dysphoria, anxiety, euphoria, apathy, disinhibition, irritability/lability, aberrant motor activity, nighttime behaviors, and changes in appetite. The higher the score, the greater the severity and frequency of these behaviors. ${ }^{18,19}$

The FTD-FRS was developed based on questions from the Cambridge Behavioral Inventory $(\mathrm{CBI})^{20}$ and the Disability Assessment for Dementia (DAD) ${ }^{21}$ It is a 30-item questionnaire that assesses: Behavior, Outing and Shopping, Household Chores, Telephone, Finances and Correspondence, Medications, Meal Preparation, Eating, Self-care and Mobility. It was developed with the purpose of assessing disease severity and progression in FTLD. ${ }^{8}$ The response options for each question are: all the time $=0$; sometimes $=0$ and never $=1$. The examiner must add the number of alternatives marked as "never" and then divide by the number of questions answered. This will generate a percentage (an index of functional preservation) which takes into account the pre-morbid state of the patient (as the tasks which were never per- formed are not considered in the score). After calculating the percentage of preservation the score should be converted to a logarithm (Table 2) and the severity of the disease is established (very mild, mild, moderate, severe, very severe and profound).

The administration of the patient protocol took about 60 minutes. The interview with informants lasted about 45 minutes. The present study was approved by the Research Ethics Committee of the Hospital of Clinics, School of Medicine, University of São Paulo, under protocol number 311,601. Caregivers of patients with dementia filled out the informed consent form and were instructed regarding the research procedures.

Statistical analysis. The Chi-square test was used to compare categorical variables between the diagnostic groups. The Kolmogorov-Smirnov test determined the presence of a normal distribution in most of the continuous variables and therefore parametric tests were required, such as Student's $t$-test. The data were entered in the Epidata software v.3.1. For statistical analysis, the SPSS v.17.0 and the Statistica v. 7.0 software packages were used. Statistical significance was set as a $\mathrm{p}$-value $<0.05$.

\section{RESULTS}

Table 3 shows the sociodemographic characteristics of participants. It can be noted that the groups were homogeneous with regards to gender, age and education. On the MMSE and the EXIT-25 there was a significant difference among the three groups, with the $\mathrm{AD}$ group

Table 3. Sociodemographic characteristics, cognitive performance, neuropsychiatric symptoms and severity levels for dementia sub-types.

\begin{tabular}{|c|c|c|c|c|c|c|}
\hline & & \multicolumn{2}{|c|}{ bvFTD $(n=12)$} & \multicolumn{2}{|c|}{$A D(n=11)$} & \multirow[b]{2}{*}{ p-value } \\
\hline & & Means & $\pm S D$ & Means & \pm SD & \\
\hline Women (\%) & & \multicolumn{2}{|c|}{$33.33 \%$} & \multicolumn{2}{|c|}{$54.54 \%$} & $0.305^{*}$ \\
\hline Age (51 to 79 years) & & 66.17 & 8.08 & 67.73 & 8.08 & 0.648 \\
\hline Schooling (4 - 20 years) & & 10.58 & 6.29 & 9.64 & 5.48 & 0.705 \\
\hline MMSE (15 to 25 points) & & 21.08 & 2.39 & 18.36 & 1.96 & 0.007 \\
\hline EXIT-25 (10 to 25 points) & & 18.67 & 3.65 & 15.00 & 3.033 & 0.017 \\
\hline ACE-R (51 to 78 points) & & 62.83 & 9.42 & 58.00 & 5.60 & 0.154 \\
\hline NPI Total (9 to 44 points) & & 18.83 & 11.15 & 17.00 & 4.92 & 0.621 \\
\hline FTD-FRS (20 to 87 points) & & 55.56 & 21.57 & 75.76 & 7.76 & 0.011 \\
\hline \multirow[t]{3}{*}{ FTD-FRS Categories } & Mild & \multicolumn{2}{|c|}{$25 \%$} & \multicolumn{2}{|c|}{$36.36 \%$} & \\
\hline & Moderate & \multicolumn{2}{|c|}{$50 \%$} & \multicolumn{2}{|c|}{$63.64 \%$} & \\
\hline & Severe & \multicolumn{2}{|c|}{$25 \%$} & \multicolumn{2}{|c|}{$0 \%$} & $0.204^{*}$ \\
\hline
\end{tabular}

p-value refers to Student's t-test, ${ }^{*}$ Chi-square test. 2. ACE-R: Addenbrooke's Cognitive Examination - Revised; MMSE: Mini-Mental State Examination; EXIT-25: Executive Interview; DAD: Disability Assessment for Dementia; NPI: Neuropsychiatric Inventory; FTD-FRS: Frontotemporal Dementia Rating Scale. Variations in amplitude of test scores shown in parentheses. 
exhibiting worst performance. Preliminary results for the FTD-FRS revealed greater levels of disability in bvFTD than in AD patients (bvFTD: $25 \%$ mild, $50 \%$ moderate and $25 \%$ severe; AD: $36.36 \%$ mild, $63.64 \%$ moderate), in spite of having similar CDR ratings (see Table 3 and Figure 1).

\section{DISCUSSION}

In this report, we present a culturally adapted, translated version of the FTD-FRS in Brazilian Portuguese. Confrontation between original and back-translated scales, and the preliminary staging results achieved in bvFTD patients suggest that our version is suitable for clinical purposes.

Results from the scale's pilot application are in line with those from the validation study, ${ }^{8}$ as FTD-FRS seemed to be capable of capturing functional and behavioral change not identified by the CDR. All participants had a score on the $C D R=1$, and yet, according to the FTD-FRS, 25\% of bvFTD patients were severely impaired. Also, in agreement with previous studies, ${ }^{20,21}$ our findings suggest that bvFTD is associated with greater functional loss and behavioral change compared to AD.

Determining disease severity in dementia, and especially in less prevalent sub-types, remains a controversial issue. There is currently a lack of consensus regarding the definition of severity in dementia and its ideal staging tools. ${ }^{8,15,22}$ Our study suggested that severity in bvFTD needs to be measured with a tool specifically designed to detect its early symptoms. Cognitive-based staging strategies are limited, since they are heavily dependent on language skills, which might overestimate disease severity, as observed in primary progressive aphasias. ${ }^{23}$ Additionally, in developing countries, cutoff scores in cognitive tests are unsuitable for dementia staging because of great variability in educational background. The FTD-FRS may provide a better understanding of disease progression in FTD, by showing which abilities are lost early and late in the disease, as it relies on collateral information. Also, in patients with $\mathrm{AD}$, the

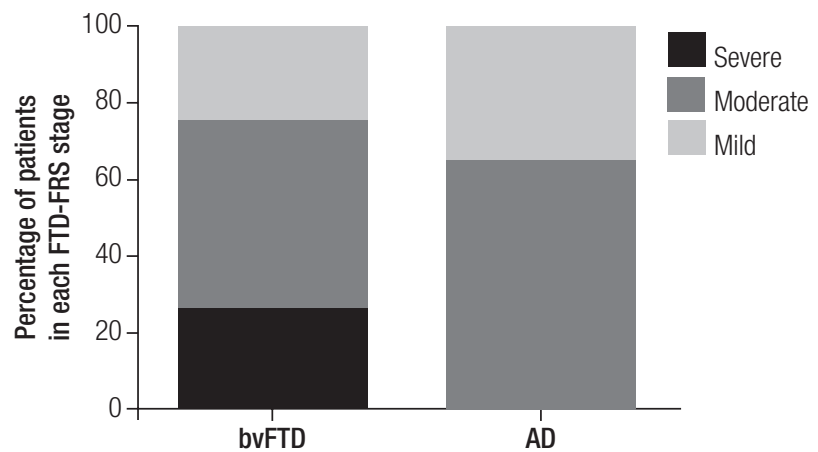

Sample was homogeneous as only mild dementia cases were included, according to Clinical Dementia Rating scale $(\mathrm{CDR}=1)$.

Figure 1. Proportion of patients in each severity category for behavioral variant frontotemporal dementia (bvFTD) and Alzheimer Disease (AD) according to Frontotemporal Dementia Rating Scale (FTD-FRS).

scale showed sensitivity in detecting severity of dementia, where a great proportion of patients with a low CDR 1 had in fact moderate severity on the FTD-FRS (64\%). The Brazilian version of the FDT-FRS seems suitable to aid staging and determining disease progression.

This study had some potential limitations. The dementia groups consisted of patients currently attending our clinics, which excludes more impaired patients living in nursing homes. We were unable to include neuropathology, which is ideally needed to confirm a definitive diagnosis. Additionally, the analyses were cross-sectional, restricting some of our interpretations. As to the strengths of the study, we may cite the fact that the sample was homogeneous as only early dementia cases were included $(C D R=1)$.

Our preliminary results suggest that the Brazilian version of the FTD-FRS is appropriate for clinical use, as it was easily understood by caregivers and family members. In addition, results are in line with previous studies using the scale, as they suggested greater functional and behavioral changes among bvFTD patients. Future studies should continue to examine the psychometric characteristics of this instrument as it may play an important role in the early diagnosis of FTLD.

\section{REFERENCES}

1. Neary D, Snowden JS, Gustafson L, et al. Frontotemporal lobar degeneration: a consensus on clinical diagnostic criteria. International workshop on frontotemporal lobar degeneration. Neurology 1998;51:15461554.

2. Rascovsky K, Hodges JR, Knopman D, et al. Sensitivity of revised diagnostic criteria for the behavioural variant of frontotemporal dementia. Brain 2011;134:2456-2477

3. Hornberger M, Piguet O, Graham AJ, Nestor PJ, Hodges JR. How preserved is episodic memory in behavioral variant frontotemporal dementia? Neurology 2010;74:472-479.

4. Leyton CE, Hornberger M, Mioshi E, Hodges JR. Application of Adden- brooke's cognitive examination to diagnosis and monitoring of progressive primary aphasia. Dement Geriatr Cogn Disord 2010;29:504-509.

5. Carthery-Goulart, MT, Knibb JA, Patterson K, Hodges JH. Semantic Dementia Versus Nonfluent Progressive Aphasia. Alzheimer Dis Assoc Disord 2012;26:36-43.

6. Charles D, Olm C, Powers J, et al. Grammatical comprehension deficits in non-fluent/agrammatic primary progressive aphasia. J Neurol Neurosurg Psychiatry 2013;1:1-8.

7. Morris JC. The Clinical Dementia Rating (CDR): current version and scoring rules. Neurology 1993;43:2412-2414.

8. Mioshi E, Hsieh S, Savage S, Hornberger M, Hodges JR. Clinical stag- 
ing and disease progression in frontotemporal dementia. Neurology 2010;74:1591-1597.

9. American Psychiatric Association. Diagnostic and statistical manual of mental disorders. 4th ed. Washington, DC: American Psychiatric Association, 1994.

10. McKahn GM , Knopman DS, Chertkow $\mathrm{H}$ et al. The diagnosis of dementia due to Alzheimer's disease: recommendations from the National Institute on Aging - Alzheimer's Association workgroups on diagnostic guidelines for Alzheimer's disease. Alzheimer's Dement 2011;7:263-269.

11. Mioshi E, Dawson K, Mitchell J, Arnold R, Hodges JR. The Addenbrooke's Cognitive Examination Revised (ACE-R): a brief cognitive test battery for dementia screening. Int J Geriatr Psychiatry 2006;21:1078-85.

12. Carvalho VA, Barbosa MT, Caramelli P. Brazilian Version of the Addenbrooke Cognitive Examination-Revised in the diagnosis of mild Alzheimer disease. Cogn Behav Neurol 2010;23:8-13.

13. Royall DR, Mahurin RK, Gray KF. Beside assessment of executive impairment: the Executive Interview (EXIT). J Amer Geriat Soc 1992; 40:1221-1226.

14. Matioli MNPS, Caramelli P. Limitations in the differential diagnosis between vascular dementia and Alzheimer disease based on brief cognitive testing. Arq Neuropsiquiatr 2010;68:185-188.

15. Chaves MLF, Camozzato AL, Godinho C. Validity of the Clinical Dementia Rating scale for the detection and stating of dementia in Brazilian patients. Alzheimer Dis Assoc Disord 2007;21:210-217.

16. Cummings JL, Mega M, Gray K, Rosenberg-Thompson S, Carusi DA,
Gornbein J. The neuropsychiatric inventory: comprehensive assessment of psychopathology in dementia. Neurology 1994;44:2308-2314.

17. Camozzato AL, Kochhann R, Simeoni C, et al. Reliability of the Brazilian Portuguese version of the Neuropsychiatric Inventory (NPI) for Alzheimer s disease patients and their caregivers. Int Psychogeriatr 2008; 20:383-393.

18. Wedderburn $\mathrm{C}$, Wear $\mathrm{H}$, Brown J, et al. The utility of the Cambridge Behavioural Inventory in neurodegenerative disease. J Neurol Neurosurg Psychiatry 2008;79:500-503.

19. Gelinas I, Gauthier L, McIntyre M., Gauthier S. Development of a functional measure for persons with Alzheimer's disease: the disability assessment for dementia. Am J OccupTher 1999;53:471-481.

20. Mioshi E, Kipps CM, Dawson K, Mitchell J, Graham A, Hodges JR. Activities of daily living in frontotemporal dementia and Alzheimer disease. Neurology 2007;68:2077-2084.

21. Lima-Silva TB, Bahia VS, Amaral-Carvalho, et al. Functional profile of patients with behavioral variant frontotemporal dementia (bvFTD) compared to patients with Alzheimer's disease and normal controls. Dement Neuropsychol 2013;7:96-103.

22. Diehl-Schimid J, Barnschein S, Pahl C, Först H, Kurtz A. Cognitive decline in the behavioral variant of frontotemporal dementia. Int Psychogeriatr 2011;23:230-237.

23. Hsieh S, Hodges JR, Leyton CE, Mioshi E. Longitudinal changes in primary progressive aphasias: differences in cognitive and dementia staging measures. Dement Geriatr Cogn Disord 2012;34:135-141. 


\section{APPENDIX A. \\ Escala de Estadiamento e Progressão da Demência Frontotemporal Frontotemporal Dementia Rating Scale - FTD-FRS}

Nome do paciente:

Respondente:

Relacionamento/parentesco com 0 paciente: À direita de cada frase, faça um círculo na frequência com que o problema ocorre. Caso a afirmação não se aplique, por exemplo, se a pessoa não cozinhava
antes, marque como não aplicável (N/A). Favor consultar o manual de pontuação e o roteiro de entrevistas antes de aplicar a escala (podem ser obtidos com os autores do artigo).

Comportamento

Frequência

1. Não tem interesse / se interessa por fazer as coisas - seus próprios interesses / atividades de lazer / novidades

Às vezes Nunca

2. Parece distante emocionalmente, não se interessa por preocupações de familiares.

3. Não coopera quando Ihe pedem para fazer algo; recusa ajuda.

4. Fica confuso ou desnorteado em ambientes estranhos,

5. É agitado/inquieto.

6. Age impulsivamente sem refletir, não tem bom senso.

7. Esquece em que dia está.

Passeios e compras

8. Tem dificuldades para usar seu meio de transporte habitual com segurança (carro, caso tenha habilitação; bicicleta ou Sempre Às vezes Nunca transporte público, caso não tenha habilitação).

9. Tem dificuldades para fazer compras sozinho (por exemplo, ir à padaria para comprar leite e pão, caso não faça as compras Sempre Às vezes Nunca N/A da casa).

\begin{tabular}{|c|c|c|c|c|}
\hline \multicolumn{5}{|l|}{ Tarefas domésticas e telefone } \\
\hline 10. Não tem interesse ou motivação para desempenhar tarefas domésticas que realizava no passado. & Sempre & Às vezes & Nunca & $\mathrm{N} / \mathrm{A}$ \\
\hline 11. Tem dificuldade para concluir adequadamente tarefas domésticas que realizava no passado (com a mesma qualidade). & Sempre & Às vezes & Nunca & $\mathrm{N} / \mathrm{A}$ \\
\hline 12. Tem dificuldade para encontrar e discar um número de telefone corretamente. & Sempre & Às vezes & Nunca & \\
\hline \multicolumn{5}{|l|}{ Finanças } \\
\hline 13. Não tem interesse por seus assuntos pessoais, como, por exemplo, suas finanças. & Sempre & Às vezes & Nunca & $\mathrm{N} / \mathrm{A}$ \\
\hline 14. Tem problemas para organizar suas finanças e pagar contas (cheques, controlar a conta do banco, contas a pagar). & Sempre & Às vezes & Nunca & N/A \\
\hline 15. Tem dificuldade na organização da correspondência (separar as contas, de propagandas ou os destinatários). & Sempre & Às vezes & Nunca & N/A \\
\hline 16. Tem problemas para lidar adequadamente com dinheiro em lojas, postos de gasolina, etc. (pagar e conferir o troco) & Sempre & Às vezes & Nunca & \\
\hline \multicolumn{5}{|l|}{ Medicações } \\
\hline 17. Tem problemas para tomar suas medicações no horário correto (esquece ou se recusa a tomá-las). & Sempre & Às vezes & Nunca & $\mathrm{N} / \mathrm{A}$ \\
\hline 18. Tem dificuldade para tomar suas medicações como foram prescritas (na dosagem correta). & Sempre & Às vezes & Nunca & N/A \\
\hline \multicolumn{5}{|l|}{ Preparo de refeições e alimentação } \\
\hline $\begin{array}{l}\text { 19. Não tem o interesse ou motivação de costume para preparar uma refeição (ou café-da-manhã, sanduíche) para si próprio } \\
\text { (avaliação com base no desempenho pré-morbido; pontuar a mesma tarefa para questões } 19,20 \text { e 21). }\end{array}$ & Sempre & Às vezes & Nunca & $\mathrm{N} / \mathrm{A}$ \\
\hline $\begin{array}{l}\text { 20. Tem dificuldade para organizar o preparo de refeições (ou um lanche, caso o paciente não seja o responsável pela cozinha) } \\
\text { (escolha de ingredientes; apetrechos de cozinha; sequência de passos; no preparo). }\end{array}$ & Sempre & Às vezes & Nunca & $\mathrm{N} / \mathrm{A}$ \\
\hline 21. Tem problemas para preparar uma refeição (ou lanche quando aplicável) sem ajuda (precisa de supervisão/ajuda na cozinha). & Sempre & Às vezes & Nunca & N/A \\
\hline 22. Não tem iniciativa para se alimentar (se não Ihe oferecerem comida, pode passar o dia todo sem comer). & Sempre & Às vezes & Nunca & \\
\hline 23. Tem dificuldade para selecionar os talheres e temperos apropriados quando se alimenta. & Sempre & Às vezes & Nunca & \\
\hline 24. Tem problemas para comer suas refeições em um ritmo normal e de forma educada (com modos apropriados). & Sempre & Às vezes & Nunca & \\
\hline 25. Quer comer as mesmas comidas repetidamente. & Sempre & Às vezes & Nunca & \\
\hline 26. Prefere alimentos doces, mais do que antes. & Sempre & Às vezes & Nunca & \\
\hline \multicolumn{5}{|l|}{ Autocuidado e mobilidade } \\
\hline 27. Tem problemas para escolher a vestimenta adequada (de acordo com a ocasião, o clima, ou a combinação de cores). & Sempre & Às vezes & Nunca & \\
\hline 28. Tem incontinência. & Sempre & Às vezes & Nunca & \\
\hline 29. Não pode ser deixado sozinho em casa por um dia inteiro (por razões de segurança). & Sempre & Às vezes & Nunca & \\
\hline 30. Está restrito à cama. & Sempre & Às vezes & Nunca & \\
\hline
\end{tabular}

